\title{
Variations in seasonal drought tolerance rankings
}

\author{
Jonathan M. Banks ${ }^{1,2}$ (D) Glynn C. Percival ${ }^{1} \cdot$ Gillian Rose $^{2}$ \\ Received: 20 July 2018 / Accepted: 18 March 2019 / Published online: 5 April 2019 \\ (c) The Author(s) 2019
}

\begin{abstract}
Key message Cultivars of Acer platanoides, A. pseudoplatanus and A. campestre show significant seasonal drought tolerance variation, identified by in vitro desiccation a whole-tree drought and water potential at turgor-loss-point.

Abstract Drought is one of the most common and significant disorders affecting tree establishment and growth, in the urban environment. Consequently, improving tree selection by the provision of quantifiable tolerance data by which to evaluate genotypes is an important area of scientific research. A number of in vitro studies address drought tolerance in isolation, at a single time point during the growing season. Using an in vitro foliar dehydration method to evaluate closely related genotypes of Acer platanoides, A. pseudoplatanus and A. campestre, drought tolerance rankings were not found to be consistent throughout the growing season (spring, summer and autumn). i.e., A. pseudoplatanus 'Negenia' was found to be comparatively drought tolerant in spring, but displayed moderate to low comparative tolerance in summer and autumn; as measured using in vitro foliar dehydration as a proxy for drought tolerance. Drought conditions are most severe and common in summer; however, this study discusses the need to consider spring tolerance in addition to summer or autumn, particularly when selecting trees for tough urban sites, prone to drought stress across all three seasons.
\end{abstract}

Keywords Drought $\cdot$ Drought tolerance $\cdot$ Foliar dehydration $\cdot$ Turgor loss point $\cdot$ Acer

\section{Introduction}

Drought is one of the most common and significant disorders affecting tree establishment and growth (Aranda et al. 2012). The frequency and intensity of drought events is likely to increase with climate change (IPCC 2007; Bartlett et al. 2014; Pflug et al. 2018); this is particularly true within urban areas, where root zone limitations (Kopinga 1991; Volder et al. 2009) and the urban heat island effect (Cregg and Dix 2001) decrease water availability and increase vapour pressure deficit and evapotranspiration, respectively. Species selection can significantly affect survival prospects (Roman et al. 2014). Low-value and short-lived plants can be rapidly replaced with plant material that exhibits more appropriate tolerance characteristics. However, for longer-lived and higher-value plants, such as urban trees, replacement is

Jonathan M. Banks

jbanks@bartlettuk.com

1 Bartlett Tree Experts, Research Laboratory (UK) Reading, Berkshire RG2 9AF, UK

2 School of Agriculture Policy and Development, The University of Reading, Reading, Berkshire RG6 6AR, UK undesirable. Appropriate tree selection for future climatic conditions is, therefore, of increasing importance to prevent tree losses and reduce intensifying demand on water-use due to inappropriate selection (Roman et al. 2014). Tree selectors, however, have been criticised for selecting trees based on aesthetic criteria, rather than tolerance traits (Vaz Monteiro et al. 2017). Additionally, the information available to tree selectors is often ambiguous, conflicting and lacking in appropriate specificity (Sjöman et al. 2015). In vitro empirical methods (namely, chlorophyll fluorescence on dehydrating foliage and measurements of turgor loss point) are available which can address some of the problems associated with the current paradigm of tree selection. However, the seasonal specificity of such tolerance evaluation methods requires further study. Drought tolerance has many components some of which are static and may be determined by the genotype others are plastic and can shift in response to water deficit events or during seasonal development. Tolerance is known to develop as water deficit events increase during the season (Sjöman et al. 2015). However, it is not yet clear if, or at what point, tolerance rankings within a group of genotypes maintain consistency throughout the course of a growing season. 
Large-scale drought trials are important (Ryan 2011) but not generally practical to undertake on a wide range of trees owing to cost and time needed to reach maturity in comparison to most crop plants. In vitro experimentation is, therefore, essential to evaluate whole-tree genotypic drought tolerance without undertaking whole-tree drought trials. Percival and Sheriffs (2002) and Faraloni et al. (2011) show dehydration of excised foliage can act as a viable proxy for whole-plant drought experiments. Plant root detachment and dehydration has also been used to represent drought stress in Arabidopsis rosettes (Catala et al. 2007). Leaf dehydration studies account for foliar anatomical and morphological adaptations such as trichomes, sunken stomata, thick cuticles and reduced leaf size. Another method currently gaining attention is the measurement or estimation of water potential at the turgor loss point $\left(\pi_{\mathrm{tlp}}\right)$ (Maréchaux et al. 2015; Sjöman et al. 2015, 2018b); this measure is indicative of the permanent wilting point (Bartlett et al. 2012b). The $\pi_{\text {tlp }}$ is known also to reflect the point below which a plant cannot take up sufficient soil water, and is, therefore, considered a 'higher-level' drought tolerance trait (Bartlett et al. 2014). Foliar-focused measurements are unlikely to account for whole-plant adaptations, such as foliage shedding, stem water storage mechanisms or structures (e.g., succulents or cacti) and deep rooting strategies, further discussed by Bartlett et al. (2012a, b). Experimentation has, however, revealed the validity of foliar-focused measurement's when compared against whole-plant studies, either directly or via meta-analysis (Percival and Sheriffs 2002; Bartlett et al. 2012b, 2014). Additionally, many drought avoidance mechanisms (foliage shedding) are undesirable for trees planted in the urban environment (Sjöman et al. 2015). Measurements which exclude these avoidance factors, such as measurements of $\pi_{\text {tlp }}$ and foliar dehydration studies, are, therefore, of potential benefit to those involved in the selection of urban trees.

A tree's ability to adapt to drought stress events throughout a season facilitates a balance between the costs and benefits of maintaining tolerance traits (Postma and Jaramillo 2008; Bigler 2016). Most water is lost from the leaves of woody plants (Pallardy 2007); therefore, adaptations are primarily located in the foliage. Stomatal closure is the primary means of reducing water loss, maintaining turgor and extending the range of foliar function under minor to moderate drought (Arndt et al. 2001). However, this reduces the rate of photosynthesis while increasing the risk of photoinhibition (Takahashi and Murata 2008). Under more severe drought, developmental water deficit tolerance mechanisms involve the maintenance, and extension of cellular tolerance to reduced relative water content (RWC). Plants can alter their drought tolerance by reallocation of root/shoot dry matter and other molecular changes (Kozlowski and Pallardy 2002). True tolerance mechanisms, however, involve the maintenance of cellular turgidity through cellular osmotic potential (osmoregulation) and tissue elasticity (Kozlowski and Pallardy 2002), both mechanisms and are capable of fluctuating throughout the course of a season.

Osmoregulation involves the local synthesis of osmotically active metabolites, resulting in osmotic adjustment (Arndt et al. 2001; Burg and Ferraris 2008), increasing osmotic gradients and maintaining cellular turgidity (Farooq et al. 2012). Turgor maintenance is required for growth to continue during drought events (Clifford 1998). Increases in inorganic ion concentrations (sodium, calcium and potassium) for this purpose, however, can perturb protein function (Burg and Ferraris 2008). Therefore organic osmolytes are also used, such as proline and glycine betaine (Bohnert 1995). Significant growth period, seasonal, environmental and species-specific fluctuations in osmolytes are known to occur (Bohnert and Jensen 1996; Murakeözy et al. 2003; Regier et al. 2010; Ryan 2011). Current evidence suggests osmolyte levels in foliage are highest in spring and lowest in the summer months (Lansac et al. 1994; Murakeözy et al. 2003; Bandurska et al. 2009). Conversely, inorganic ions and carbohydrates tend to accumulate across the seasons (Murakeözy et al. 2003); however, significant seasonal and intraspecific variations in stored and utilised carbohydrates in response to drought are known to occur (Regier et al. 2010; McDowell 2011; Ryan 2011; Brunner et al. 2015). Osmoregulation is not, however, a universal strategy (Pallardy 2007); Acer saccharum (Bahari et al. 1985; Sjöman et al. 2015), Fagus sylvatica and Quercus petraea (Backes and Leuschner 2000), for example, were reported to exhibit little or no osmotic adjustment.

Tissue elasticity or elastic modulus $(\varepsilon)$ can also influence drought tolerance variation throughout a season as leaves become more rigid. Elastic modulus is defined as the pressure required to cause a unit change in cell volume (Verslues et al. 2006). It is well documented that (other variables being equal) a more elastic tissue, low $\varepsilon$, is more capable of maintaining turgor under relatively large water losses (Kozlowski and Pallardy 2002; Verslues et al. 2006; Pallardy 2007). However, highly elastic cells which exhibit significant osmotic adjustment may be at risk of damage upon rehydration (Clifford 1998). Decreased elasticity (greater rigidity, high $\varepsilon$ ) tends to maintain RWC as water potential declines and cell volume is maintained (Clifford 1998; Pallardy 2007). This is observed in scleromorphic and coriaceous (texture of leather) leaves which are often considered drought resistant (Ogaya and Peñuelas 2006; De Micco and Aronne 2012). Both increases and decreases in elasticity, therefore, have been associated with tolerance to drought (Clifford 1998; Pallardy 2007). Acer saccharum trees have been shown to display seasonal variations in $\varepsilon$ from ca. $5 \mathrm{MPa}$ in mid-May to $18 \mathrm{MPa}$ in July, lowering again to $7 \mathrm{MPa}$ in October (Tyree et al. 1978). However, differences in elastic response to drought have been noted 
to diverge even in closely related species of the same genus (Pallardy 2007). Divergence may in some cases, however, be as a result of other ecological strategies such as resistance to herbivory (Powell et al. 2017).

Acer saccharum also exhibits seasonal variations in $\pi_{\text {tlp }}$ (incipient plasmolysis), identifying values ca. $1 \mathrm{MPa}$ in May rising rapidly to ca. $1.8 \mathrm{MPa}$ by June before gradually rising to ca. $2 \mathrm{MPa}$ by October (Tyree et al. 1978). Sjöman et al. $(2015,2018)$ also identify seasonal change in $\pi_{\text {tlp }}$ within a range of Acer and Magnolia species and cultivars. They identify that spring tolerance is lower and the species tested rank differently in comparison to summer tolerance (Sjöman et al. 2015, 2018b). Little information is, however, available to suggest if tolerance levels are maintained or decline following summer tolerance acquisition. Additional data regarding seasonal variation is not available for other species and cultivars within the Acer genus. A range of information is important as differences in both osmoregulation and elastic adjustment have been noted in closely related species (Pallardy 2007). This study uses species and cultivars from the Acer genus as a model for the drought tolerance of very closely related deciduous tree species. The seasonal consistency of foliar desiccation is determined and compared to summer measurements of $\pi_{\text {tlp }}$ and whole-tree drought tolerance.

\section{Materials and methods}

\section{Plant material}

All Acer species represented within this trial are commonly utilised as urban street trees. A range of genotypes with contrasting intraspecific foliar and crown characteristics were selected. All genotypes used were grafted onto their respective species-type rootstocks. 87-year-old $4.2 \mathrm{~m}( \pm 0.3)$ tall trees with a DBH of $50.7 \mathrm{~mm}( \pm 7.9)$ growing in 45 L Light Pots ${ }^{\mathrm{TM}}$ (white, mypex woven grow bags) grafted onto their respective species-type rootstocks were used for this experiment. The potting substrate consisted of a 50:50 green waste and pine bark compost mix, with a $\mathrm{pH}$ of 7.7. Ten trees from each of the following genotypes were used: A. campestre, A. campestre 'Louisa Red Shine', A. platanoides 'Drummondii', A. platanoides 'Emerald Queen', A. platanoides 'Princeton Gold', A. platanoides 'Royal Red', A. pseudoplatanus 'Negenia', and A. pseudoplatanus 'Spaethii'. Further information on the selected genotypes is displayed in Table 1. For the duration of this experiment, all trees were kept outside, at Barcham Trees nursery, Ely, Cambridgeshire $\left(52.366923^{\circ} \mathrm{N}\right.$, $\left.0.315864^{\circ} \mathrm{W}\right)$. All experimental trees were arranged in a single row, either side of which was bordered by two rows of nursery trees of equal size to minimise edge effects.
Experimental trees were arranged in 5 repeat blocks, each containing 16 randomly placed specimens representing all aforementioned Acer genotypes for both the droughted and watered treatment.

\section{Whole-tree drought treatment}

A watering treatment (irrigated or non-irrigated) was alternated between blocks, and all trees allocated to the irrigated treatment were drip-irrigated with ca. 51 of water per day. Drought treatment was initiated by detaching irrigation lines from non-irrigated trees. Drought was augmented by installing black plastic rain covers over all root balls (irrigated and non-irrigated) to exclude rainfall and by raising all pots ca. $75 \mathrm{~mm}$ off the ground to avoid water uptake from the ground, which was covered in pea gravel.

Drought was initiated on the 27th July 2016 and continued until the 9th of August. Chlorophyll fluorescence and soil moisture measurements were made on three leaves per tree on the 18th July ( $-216 \mathrm{~h}$ prior to irrigation removal), 4th August (192 h) and 9th August (310 h).

Environmental conditions were monitored using a Tiny Tag (TGP-4500) temperature and relative humidity sensor. The conditions during the drought trial were $18.1^{\circ} \mathrm{C}$ $( \pm 3.6), 63 \% \mathrm{RH}( \pm 34.5), \mathrm{VPD} 0.78 \mathrm{kPa}( \pm 0.69)$.

Percent volumetric water content (VWC) was measured at each timepoint using a Delta-T Devices SM150 soil moisture sensor kit (Delta-T Devices Ltd, Cambridge) generating volumetric soil moisture content (VMC) data with $\pm 3 \%$ accuracy. The probe permits soil moisture readings to be taken with minimal root or soil disturbance by gently pushing the two $51 \times 2.5 \mathrm{~mm}$ probes through the Light Pots $^{\mathrm{TM}} 10-15 \mathrm{~cm}$ from the base of the pot. Soil moisture data were used to confirm a significant difference occurred between watered and droughted trees $(p \leq 0.001)$ (Fig. 1).

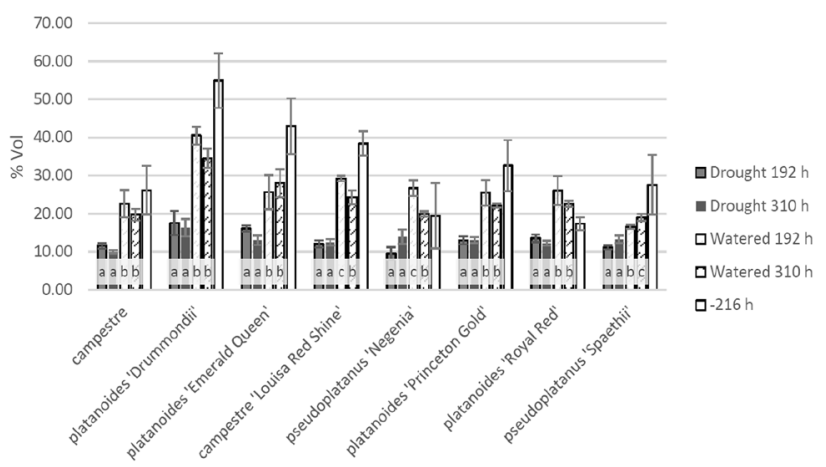

Fig. 1 Percent volumetric water content for droughted and control genotypes, $192 \mathrm{~h}$ and $310 \mathrm{~h}$ following irrigation removal. Error bars show standard error, letters denote significant differences within genotypes $(n=5) .-216 \mathrm{~h}$ prior to drought initiation includes both droughted and watered groups; it is included for comparison but omitted from statistical analysis $(n=2)$ 
Table 1 Available information on the species used within this study

\begin{tabular}{|c|c|c|c|}
\hline Species 'Cultivar' & $\begin{array}{l}\text { Common } \\
\text { Name }\end{array}$ & Key Features & Ecology/Drought tolerance \\
\hline A. pseudoplatanus & Sycamore & $\begin{array}{l}\text { Fast growing deciduous spreading tree } \\
\text { Considered a British non-native, introduced to the UK in ca. } \\
1250 \text { (Southwood 1961). }\end{array}$ & $\begin{array}{l}\text { Recommended for an exposed position (Brickell 1989). } \\
\text { Drought sensitive in comparison to F. sylvatica, F. excelsior, Q. petraea, T. platyphyllos and P. avium. } \\
\text { Scherrer et al. (2011). } \\
\text { Tolerant of prolonged periods of dry (cat. 10) and very wet soil (cat. 3) (Bassuk et al. 2009). } \\
\text { Very adaptable to soil types, preferably well drained (Dirr 1990). } \\
2.75 \pm 0.16 \text { (Niinemets and Valladares 2006). } \\
\pi_{\text {TLP }}-2.70 \mathrm{MPa} \text { (permanent wilting point) (Sjöman et al. 2015) }\end{array}$ \\
\hline $\begin{array}{l}\text { 'Spaethii' } \\
\text { ('Atropurpureum', } \\
\text { 'Purpureum') }\end{array}$ & & Leaves dark green above, rich purple below (Dirr 1990) & $\begin{array}{l}\text { Thought to be less tolerant than the straight species to insect and disease factors, leaf scorch, } \\
\text { sunscald and borer infestations (Bassuk et al. 2009). }\end{array}$ \\
\hline 'Negenia' & & $\begin{array}{l}\text { Vigorous conical shaped tree with red-stalked, large dark } \\
\text { green leaves (Hillier 1993). }\end{array}$ & Tolerant to poor soil conditions (van den Berk and van den Berk 2015). \\
\hline A. campestre & $\begin{array}{l}\text { Field } \\
\text { Maple }\end{array}$ & $\begin{array}{l}\text { Low branching compact tree commonly found in field } \\
\text { hedgerows and brownfield sites } \\
\text { Native to the UK (Southwood 1961). }\end{array}$ & $\begin{array}{l}\text { Tolerant of prolonged periods of dry (cat. 12), and consistently moist soil (cat. 4). (Bassuk et al. } \\
\text { 2009). } \\
\text { Cat. } 2.93 \pm 0.32 \text { (Niinemets and Valladares 2006). } \\
\text { Tolerant of any soil except dry infertile and sandy (van den Berk and van den Berk 2015). } \\
\pi_{\text {TLP }-3.00 \mathrm{MPa} \text { (permanent wilting point) (Sjöman et al. 2015) }}\end{array}$ \\
\hline 'Louisa Red Shine' & & Leaves have a slight red coloration in spring. & Tolerant to all soil types except dry infertile and sandy (van den Berk and van den Berk 2015). \\
\hline A. platanoides & $\begin{array}{l}\text { Norway } \\
\text { Maple }\end{array}$ & $\begin{array}{l}\text { Vigorous deciduous spreading tree with clusters of yellow } \\
\text { flowers in mid spring, before leaves appear. } \\
\text { Considered an invasive plant in parts of the United states of } \\
\text { America (Martin 1999). } \\
\text { Considered a British non-native. Native to continental Europe } \\
\text { (Webb and Kaunzinger 1993). }\end{array}$ & $\begin{array}{l}\text { Tolerant of prolonged periods of dry (cat. 10) and very wet soil (cat. 3) (Bassuk et al. 2009). } \\
\text { Cat. } 2.73 \pm 0.16 \text { (Niinemets and Valladares 2006). } \\
\pi_{\text {TLP }-3.09 \mathrm{MPa} \text { (permanent wilting point) (Sjöman et al. 2015) }}\end{array}$ \\
\hline 'Drummondii' & & $\begin{array}{l}\text { Variegated cultivar, leaves have creamy-white edges turning } \\
\text { yellowish in autumn (Brickell 1989; Bassuk et al. 2009). }\end{array}$ & Supposedly the best of its class (Dirr 1990). \\
\hline 'Emerald Queen' & & $\begin{array}{l}\text { Upright when young, leaves have a reddish tint in spring and } \\
\text { are bright yellow in autumn (Hillier 1993) }\end{array}$ & $\begin{array}{l}\text { Less tolerant than 'Summershade' similar to 'Deborah' (Fini et al. 2009). } \\
\text { One of the best Norway Maples for urban plantings (Dirr 1990). }\end{array}$ \\
\hline 'Royal Red' & & $\begin{array}{l}\text { Deep reddish-purple leaves (Brickell 1989) } \\
\text { Underlying suspicion that 'Royal Red' and 'Crimson King' are } \\
\text { the same tree (Dirr 1990) }\end{array}$ & $\begin{array}{l}\text { Considered more susceptible to pest problems than the straight species, but more tolerant and } \\
\text { slower growing than 'Crimson King' (Bassuk et al. 2009). } \\
\text { Supposedly hardier than 'Crimson King' (Dirr 1990). }\end{array}$ \\
\hline ‘Princeton Gold’ & & $\begin{array}{l}\text { Shows yellow spring and summer foliage and may fade to a } \\
\text { darker yellow in autumn (Bassuk et al. 2009). }\end{array}$ & No source available \\
\hline
\end{tabular}

\section{In vitro dehydration treatment}

Three leaves from each of the 80 experimental trees were collected. Leaves were collected from the second and third node region as these displayed appropriate maturity and would putatively provide greater consistency. Spring foliage collection commenced once foliage was deemed to have reached maturity following leaf flush, i.e., developed mature colouration and structure. This occurred on the 11th May 2016 (hereafter referred to as spring). Summer foliage collection took place on 20th June 2016 (summer). Autumn collection occurred immediately as the first signs of senescence [leaf colour change (Ougham et al. 2005)] were visible in nearby healthy early indicator species (Prunus spp.), this occurred on the 23rd September 2015 (autumn). Initial measurements for each season were confirmed to demonstrate a "normal" polyphasic OJIP fluorescence rise to ensure immaturity or senescence would not influence results (data not shown) (Holland et al. 2014). Immediately after removal, all leaves were sealed in Ziploc plastic bags and kept in the dark while being transferred to the laboratory. Chlorophyll fluorescence (CF) was measured on these leaves between 11th and 16th May 2016 (spring), 21st and 29th June 2016 (summer), 23rd and 26th September 2015 (autumn). Measurements were initiated immediately upon arrival at the laboratory. Immediately after the first measurements, leaves were laid out across the laboratory bench and left to dehydrate. Leaves were arranged in a completely randomised block design ensuring each leaf had $>1 \mathrm{~cm}$ peripheral zone to reduce effects on nearby leaves. Laboratory conditions were measured using Tinytag plus TGP-4500 (Gemini Data Loggers Ltd. Chichester, West Sussex, UK). Vapour pressure deficit (VPD) was calculated in accordance with Kirkham (2014) and Shamshiri et al. (2017).

The laboratory was kept at an average VPD of: 0.34 $( \pm 0.13)$ spring, $0.57( \pm 0.14)$ summer, and $0.34( \pm 0.15)$ autumn. The windowless laboratory was kept in darkness at all times apart from when measurements were taking place ( $<3 \mathrm{~h}$ per day). Measurements of $\mathrm{CF}$ were taken each day at: $8,22,30,46,72$ and $120 \mathrm{~h}$ after removal from the trees (spring); 20, 43, 67, 91, 163 and $211 \mathrm{~h}$ (summer); 5, 25, 29, 46 and $79 \mathrm{~h}$ (autumn).

\section{Pressure-volume curves}

Pressure-volume $(\mathrm{P}-\mathrm{V})$ curves were calculated between the 12th and 22nd of July 2016 in accordance with the sap expression method; similar to that used by Parker and Pallardy (1988). Six healthy, representative leaves were collected from each genotype at random from the 80 experimental trees throughout the measurement period. Leaves were collected and taken to the laboratory in sealed plastic bags within $15 \mathrm{~min}$. Petioles were re-cut underwater and left to rehydrate overnight (15-20 h). Leaves were then 
sealed inside a pressure chamber (model 1505D EXP, PMS instruments Co., Albany, USA). The average initial balance pressure was $-0.07 \mathrm{MPa}( \pm 0.017)$. Leaves which did not hydrate to an initial water potential of $>-0.2 \mathrm{MPa}$ were discarded (Lenz et al. 2006). Incremental pressures of $0.2 \mathrm{MPa}$ were applied to the leaf, beginning at $0.2 \mathrm{MPa}$. $\mathrm{P}-\mathrm{V}$ curves were halted at $2.2 \mathrm{MPa}$ if at least three data points were in the linear portion of the graph. Total expressed sap at each pressure was absorbed in pre-weighed $1.5 \mathrm{ml}$ Eppendorf tubes filled with dry low-lint absorbent tissue paper (Kimtech Science, Kent, UK). Tubes were handled and opened for the minimum possible time during sap collection to prevent evaporation. $\mathrm{P}-\mathrm{V}$ curves were plotted as accumulated expressed sap on the $x$-axis, against -1 /applied pressure (MPa) (y-axis). Osmotic potential at full turgor $\left(\pi_{0}\right)$ was determined by extrapolation of the linear portion of the graph to zero expressed sap (Tyree and Hammel 1972). Water potential at the turgor loss point $\left(\pi_{\mathrm{tlp}}\right)$ was calculated as the $Y$ axis value at the intersection point of the linear and exponential models (i.e., $Y=$ when $\Delta x$-axis lin. and exp. $=0$ ) (Jane and Green 1983) (Fig. 2).

\section{Chlorophyll fluorescence}

Chlorophyll fluorescence has been shown to be a viable quantitative indicator of drought stress and survival (Woo et al. 2008; Jedmowski et al. 2015; Kalaji et al. 2017; Banks 2018). Measurements were performed on leaf material from both the whole-tree drought and foliar dehydration. Following dark adaptation (30 min) measurements were performed using a Pocket Plant Efficiency Analyser (PEA) device (Hansatech instruments ltd., Norfolk). Dark adaptation was still necessary despite the laboratory being kept in near-complete darkness as light was necessary when working in the laboratory. Chlorophyll fluorescence was induced by a $1 \mathrm{~s}$ flash of light $\left(650 \mathrm{~nm}, 1500 \mu \mathrm{mol} / \mathrm{m}^{2} / \mathrm{s}\right)$ provided by an array of three light-emitting diodes over a $4 \mathrm{~mm}$ diameter of leaf surface. The ratio of variable $\left(F_{\mathrm{V}}=F_{\mathrm{M}}-F_{0}\right)$ to maximal fluorescence $\left(F_{\mathrm{M}}\right)$ was calculated. $F_{0}$ at $T_{\hat{0}}$ was used during this study (Banks 2017). The sensitivity of $F \mathrm{v} / F \mathrm{~m}$ is known to vary in response to drought stress (Banks 2018),

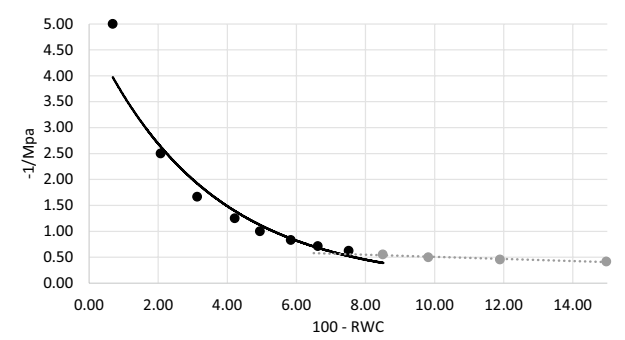

Fig. 2 An example pressure-volume $(\mathrm{P}-\mathrm{V})$ curve. Linear portion $y=-0.0205 x+0.7131 R^{2}=0.9307$, exponential $y=4.8672 \mathrm{e}^{-0.297 x}$ $R^{2}=0.9609$ researchers should use caution relying on this parameter alone for drought trials particularly when stress is not severe.

Time for the chlorophyll fluorescence parameter $F \mathrm{v} / F \mathrm{~m}$ to decline by $50 \%$ was calculated per tree, using a linear regression and results per tree were subsequently analysed (Drought $n=5 R^{2}=0.85 \pm 0.21$, Dehydrated $n=10$ average $\left.R^{2}=0.79 \pm 0.11\right)$.

\section{Relative water content}

Due to the size of the trial, it was not possible to measure relative water content for each leaf. Time was, therefore, used as a substitute for relative water content (RWC). To confirm this was an appropriate assumption in a subset of this trial $(n=15)$, RWC was plotted against time and a strong correlation was observed, this was in agreement with data displayed by Rastogi et al. (2002) and Faraloni et al. (2011). These data confirm time can be used as a proxy in this experiment, it is important to note, however, that RWC should not be predicted using these data (Fig. 3).

\section{Statistical analysis}

Statistical analysis was performed using GenStat 17. Time series data were analysed using a residual maximum likelihood (REML) model. Following this, analysis of variance (ANOVA) was performed on transformed data (time for 50\% reduction in Fv/Fm) to assess for differences between Acer genotypes for each measurement season individually. Post hoc analysis was performed using a Tukey's multiple comparison test at the $95 \%$ level.

Spearman's rank correlation coefficient $\left[\rho\right.$ (rho) or $\left.r_{\mathrm{s}}\right]$ was calculated to determine the similarity in ranking between each categorical variable on a per tree basis. The strength of rank correlations was interpreted using the following thresholds (Table 2).

\section{Results}

Significant differences $(p \leq 0.05)$ were observed within whole-tree drought, $\pi_{\mathrm{tlp}}$, and dehydration for all seasons between the Acer genotypes evaluated. Table 3 identifies the time taken for Acer genotypes to decline by $50 \%$, with $\pi_{\text {tlp }}$ included for comparison. It was not possible to achieve consistent environmental conditions between seasons, resulting in dehydration occurring more rapidly in summer owing to a higher VPD (ca. $+4{ }^{\circ} \mathrm{C}$ in comparison to autumn and spring), this difference prevents direct comparison of raw values. However, ranking genotypes, relative to the rankposition within the other seasons facilitates comparison between seasons. To provide this, a Spearman's rank correlation coefficient $\left(r_{\mathrm{s}}\right)$ was performed (Table 4$)$ on the data 
displayed in Table 3. This allows the relative rank of each season to be compared. Results identify a progression in conformity towards the drought tolerance ranking; a negative weak $\left(r_{\mathrm{s}}-0.21\right)$, strong $(0.62)$ to moderate $(0.52)$ rank correlation (Table 4) can be observed developing from spring to summer and autumn, respectively, in comparison to the rank observed in the summer whole-tree drought.

A more negative $\pi_{\mathrm{tlp}}$ infers greater drought tolerance, therefore, the corresponding $r_{\mathrm{s}}$ values are negative. In this study, the $\pi_{\text {tlp }}$ conforms strongly to the rankings achieved for summer and autumn foliar dehydration $(-0.64$ and -0.74 $r_{\mathrm{s}}$, respectively) and summer drought $\left(-0.6 r_{\mathrm{s}}\right)$ (Table 4$)$. Very strong similarity exists between summer and autumn $\left(r_{\mathrm{s}} 0.81\right)$ suggesting that in this trial tolerance is maintained from autumn into summer the following year.

\section{Discussion}

Spring drought tolerance is lower in both annual plants (Farooq et al. 2012) and deciduous trees (Sjöman et al. 2015, 2018a, b) when compared to summer tolerance. Sjöman et al. $(2015,2018 \mathrm{a})$ identifies, however, that Acer species which are most drought tolerant in spring are not necessarily the most tolerant in summer. It is, therefore, important to clarify if tolerance ranks are maintained throughout the season. This will determine the applicable seasonal range for this type of categorical data.

Data presented here adds further evidence that foliar dehydration and $\pi_{\text {tlp }}$ can identity whole-plant drought tolerance (Jane and Green 1983; Percival and Sheriffs 2002; Baltzer et al. 2008; Faraloni et al. 2011; Bartlett et al. 2012a; Sjöman et al. 2015, 2018b). However, the timing of dehydration studies is highly important. Spring dehydration tolerance is not concurrent with summer $\pi_{\text {tlp }}$, drought or summer dehydration tolerance (Table 4). Tolerance ranks approach parity with whole-tree summer drought tolerance

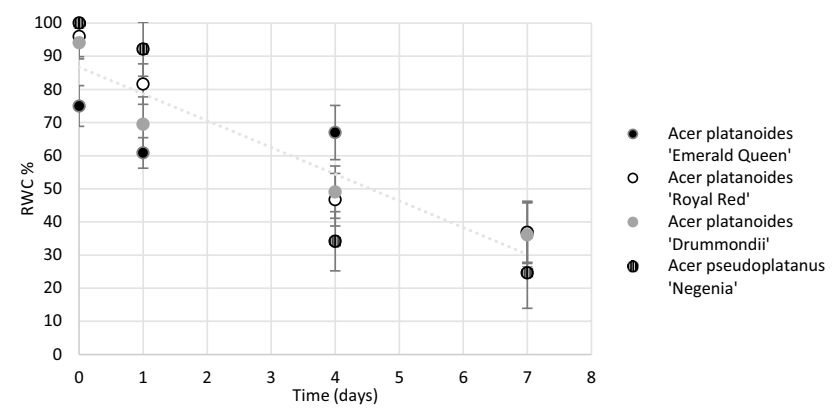

Fig. 3 Relative water content (RWC) (\%) plotted against time (days) for four selected species. $n=15$. Error bars show standard error. Linear regression expressed for all four species was $y=-8.0701 x+86.733 R^{2}=0.808$

and $\pi_{\mathrm{tlp}}$ after the spring season. A very strong correspondence exists between autumn and summer dehydration ranks, suggesting tolerance levels are maintained into the autumn. The autumn dehydration experiment, however, occurred during the previous year, and, therefore, these data suggest that consistency of rank is present in successive years, further work under differing drought exposure is nevertheless required to fully confirm this. The timing of drought events in perennial plants is clearly an important factor determining species tolerance or survival. Sjöman et al. (2015) rank tolerance based on summer estimates of $\pi_{\text {tlp }}$ while also reporting spring values. Water deficit is most severe in summer (Lansac et al. 1994), therefore, species with a greater summer tolerance are likely more desirable. However, a combined high spring and summer tolerance is also desirable if a risk of spring drought is present. Drought stress is more likely to occur in all seasons in urban areas where limited rooting volumes and increased root injury are likely (Clark and Kjelgren 1990; Savi et al. 2015). Data presented by Sjöman et al. (2015) identify Acer monspessulanum as the most summer drought tolerant $\left(\pi_{\text {tlp }}\right.$ ca. $\left.-4.2 \mathrm{MPa}\right)$ species in comparison to the 27 other Acer genotypes evaluated. However, Acer rubrum 'Northwood' would be significantly more tolerant in a spring drought event, $\pi_{\text {tlp }}$ ca. $-2.6 \mathrm{MPa}$ vs $-1.7 \mathrm{MPa}$ for $A$. monspessulanum while also maintaining a relatively low summer $\pi_{\text {tlp }}$ of ca. $-3.5 \mathrm{MPa}$ (Sjöman et al. 2015). In urban areas, therefore, A. rubrum 'Northwood' may be recommended over the more summer drought tolerant $A$. monspessulanum. In this study, A. platanoides 'Princeton Gold' was consistently the most dehydration tolerant (Table 3). However, in the whole-tree drought study the variegated A. platanoides 'Drummondii' was significantly more drought tolerant (Table 3). Soluble carbohydrates in white non-photosynthetic tissue have been shown to not respond to drought to the same degree as green tissue (Pattanagul and Madore 1999). Additionally, white foliage has a lower stomatal conductance (Aphalo and Sánchez 1986) and higher reflectance (Smith 1986) than its green counterpart, irrespective of drought treatments. This putatively suggests that the variegation in this genotype facilitates an avoidance mechanism which was not identified in detached leaves or when using $\pi_{\text {tlp }}$. Variegation may have reduced total photoinhibition because of the lack of photosynthetic activity and reduced water loss because of

Table 2 Spearman's rank correlation coefficient interpretations (Weir 2018)

\begin{tabular}{ll}
\hline$r_{\mathrm{s}}$ & Interpretation \\
\hline $0.00-0.19$ & Very weak \\
$0.20-0.39$ & Weak \\
$0.40-0.59$ & Moderate \\
$0.60-0.79$ & Strong \\
$0.80-1.0$ & Very strong \\
\hline
\end{tabular}


Table 3 Summary of means including, time (hours) for $50 \%$ reduction in $F \mathrm{v} / F \mathrm{~m}$ and mean $\pi_{\mathrm{tlp}}$ (MPa) for the Acer genotypes tested

\begin{tabular}{|c|c|c|c|c|c|}
\hline \multirow[t]{2}{*}{ Sp. cultivar } & \multicolumn{4}{|l|}{ In vitro } & \multirow{2}{*}{$\begin{array}{l}\text { Whole tree } \\
\text { Drought }(\mathrm{h})\end{array}$} \\
\hline & $\begin{array}{l}\text { Spring dehydration }(\mathrm{h} \text {, } \\
\left.F_{\mathrm{V}} / F_{\mathrm{M}}\right)\end{array}$ & $\begin{array}{l}\text { Summer dehydration } \\
\left(\mathrm{h}, F_{\mathrm{V}} / F_{\mathrm{M}}\right)\end{array}$ & $\begin{array}{l}\text { Autumn dehydration } \\
\left.\text { (h, } F_{\mathrm{V}} / F_{\mathrm{M}}\right)\end{array}$ & $\pi_{\mathrm{tlp}}(\mathrm{MPa})$ & \\
\hline pseudoplatanus 'Spaethii' & $146.7 \mathrm{a}$ & $94.0 \mathrm{a}$ & $71.6 \mathrm{ab}$ & $-1.45 \mathrm{ab}$ & $269.7 \mathrm{a}$ \\
\hline campestre 'Louisa Red Shine' & $85.8 \mathrm{a}$ & $96.9 \mathrm{a}$ & $49.5 \mathrm{a}$ & $-1.33 a b$ & $259.3 \mathrm{a}$ \\
\hline campestre & $177.4 \mathrm{ab}$ & $106.0 \mathrm{ab}$ & $56.9 \mathrm{ab}$ & $-1.28 \mathrm{a}$ & $260.4 \mathrm{a}$ \\
\hline pseudoplatanus 'Negenia' & $301.4 \mathrm{bc}$ & $112.4 \mathrm{~b}$ & $84.5 \mathrm{ab}$ & $-1.44 a b$ & $265.8 \mathrm{a}$ \\
\hline platanoides 'Drummondii' & $94.3 \mathrm{a}$ & $121.4 \mathrm{bc}$ & $64.9 \mathrm{ab}$ & $-1.49 a b$ & $449.7 \mathrm{c}$ \\
\hline platanoides 'Royal Red' & $113.1 \mathrm{a}$ & $127.9 \mathrm{~cd}$ & $103.0 \mathrm{~b}$ & $-1.39 \mathrm{ab}$ & $382.7 \mathrm{bc}$ \\
\hline platanoides 'Emerald Queen' & $134.4 \mathrm{a}$ & $130.7 \mathrm{~cd}$ & $96.7 \mathrm{ab}$ & $-1.55 a b$ & $342.9 \mathrm{abc}$ \\
\hline platanoides 'Princeton Gold' & $346.7 \mathrm{c}$ & $140.5 \mathrm{~d}$ & $219.9 \mathrm{c}$ & $-1.67 b$ & $286.7 \mathrm{ab}$ \\
\hline$p$ & $<0.001$ & $<0.001$ & $<0.001$ & 0.031 & $<0.001$ \\
\hline
\end{tabular}

Letters denote significant differences between genotypes at the $95 \%$ confidence interval

Note that comparison between measurement methods should not be attempted using raw data, rather, comparing relative genotype positions facilitates assessment between seasons and methods

Table 4 Spearman's rank correlation coefficient matrix comparing the time for $50 \%$ reduction in $F \mathrm{v} / F \mathrm{~m}$ between dehydration seasons, $\pi_{\text {tlp }}$ and a controlled drought event

\begin{tabular}{|c|c|c|c|c|c|c|}
\hline & & 1 & 2 & 3 & 4 & 5 \\
\hline Leaf dehydration (spring) & 1 & 1 & & & & \\
\hline Leaf dehydration (summer) & 2 & 0.17 & 1 & & & \\
\hline Leaf dehydration (autumn) & 3 & 0.45 & 0.81 & 1 & & \\
\hline$\pi_{\mathrm{tlp}}$ & 4 & -0.19 & -0.64 & -0.74 & 1 & \\
\hline Whole-tree drought & 5 & -0.21 & 0.62 & 0.52 & -0.60 & 1 \\
\hline
\end{tabular}

All trials conducted during the 2016 season with the exception of the autumn dehydration conducted in 2015

the lower stomatal aperture and higher reflectance in the white portions of these leaves. Ecological evidence supports this assumption; Smith (1986) identifies an advantage of increased variegation in clearings with higher drought risks but additionally high availability of photosynthetically active radiation.

The progression in conformity to the summer drought rank observed here suggests that drought tolerance is required to develop, to provide an accurate summer ranking. However, some evidence from well-watered experiments suggests tolerance acclimation may be genetically "programmed" (Bahari et al. 1985; Kozlowski and Pallardy 2002) and not necessarily as a result of the plant's water deficit history. It is clear from these data, however, that there is a seasonal or developmental element for tolerance acclimation. Later season evaluations may provide more opportunity for drought exposure or tolerance development; however, an undesirable, slight reduction in conformity to a summer drought rank would be expected to be observed later in the season. Seasonal tolerance patterns within evergreen plants are an area requiring further study.

\section{Conclusion}

This study adds to evidence suggesting that foliar dehydration tolerance can act as a proxy for whole-tree drought tolerance, evaluated in this study using deciduous genotypes from the genus Acer. We suggest species which exhibit both high spring and summer drought tolerances are more suitable for planting in urban areas than species which only exhibit summer tolerance. Caution is, however, recommended as other factors are associated with drought tolerance and tree selection more generally. However, the increase in measurements detailing drought tolerance selection metrics is essential to progress from the current paradigm of tree selection.

Author contribution statement JB performed the field work and laboratory analysis, prepared figures, and wrote the manuscript. GP and GR provided supervisory support during the experiment and commented on the manuscript.

Acknowledgements The author thanks Kerry Renshaw for helpful advice and discussions on the manuscript. The author also thanks Dr. 
Andrew Hirons and Dr Andrew Daymond for helpful advice on the paper during the corresponding authors' viva examination. Additional thanks are due to Barcham Trees and Bartlett Tree Experts for supporting this research.

\section{Compliance with ethical standards}

Conflict of interest The authors declare that they have no conflict of interest.

Open Access This article is distributed under the terms of the Creative Commons Attribution 4.0 International License (http://creativeco mmons.org/licenses/by/4.0/), which permits unrestricted use, distribution, and reproduction in any medium, provided you give appropriate credit to the original author(s) and the source, provide a link to the Creative Commons license, and indicate if changes were made.

\section{References}

Aphalo PJ, Sánchez R (1986) Stomatal responses to light and drought stress in variegated leaves of Hedera helix. Plant Physiol 81:768773. https://doi.org/10.1104/pp.81.3.768

Aranda I, Gil-Pelegrín E, Gascó A et al (2012) Drought response in forest trees: from the species to the gene. Springer, Berlin

Arndt SK, Clifford SC, Wanek W et al (2001) Physiological and morphological adaptations of the fruit tree Ziziphus rotundifolia in response to progresif drought stress. Tree physiol 21:705-715

Backes K, Leuschner C (2000) Leaf water relations of competitive Fagus sylvatica and Quercus petraea trees during 4 years differing in soil drought. Can J For Res 30:335-346. https://doi. org/10.1139/x99-205

Bahari ZA, Pallardy SG, Parker WC (1985) Photosynthesis, water relations, and drought adaptation in six woody species of OakHickory forests in central Missouri. For Sci 31:557-569

Baltzer JL, Davies SJ, Bunyavejchewin S, Noor NSM (2008) The role of desiccation tolerance in determining tree species distributions along the Malay-Thai Peninsula. Funct Ecol 22:221-231. https:// doi.org/10.1111/j.1365-2435.2007.01374.x

Bandurska H, Płachta M, Woszczyk M (2009) Seasonal patterns of free proline and carbohydrate levels in cherry laurel (Prunus laurocerasus) and ivy (Hederea helix) leaves and resistance to freezing and water deficit. Dendrobiology 62:3-9

Banks JM (2017) Continuous excitation chlorophyll fluorescence parameters: a review for practitioners. Tree Physiol 37:11281136. https://doi.org/10.1093/treephys/tpx059

Banks JM (2018) Chlorophyll fluorescence as a tool to identify drought stress in Acer genotypes. Environ Exp Bot 155:118-127. https:// doi.org/10.1016/j.envexpbot.2018.06.022

Bartlett MK, Scoffoni C, Ardy R et al (2012a) Rapid determination of comparative drought tolerance traits: using an osmometer to predict turgor loss point. Methods Ecol Evol 3:880-888. https:// doi.org/10.1111/j.2041-210X.2012.00230.x

Bartlett MK, Scoffoni C, Sack L (2012b) The determinants of leaf turgor loss point and prediction of drought tolerance of species and biomes: a global meta-analysis. Ecol Lett 15:393-405. https ://doi.org/10.1111/j.1461-0248.2012.01751.x

Bartlett MK, Zhang Y, Kreidler N et al (2014) Global analysis of plasticity in turgor loss point, a key drought tolerance trait. Ecol Lett 17:1580-1590. https://doi.org/10.1111/ele.12374

Bassuk N, Curtis D, Marranca B, Neal B (2009) Recommended urban trees: site assessment and tree selection for stress tolerance. Urban Horticulture Institute, Cornell University, Ithaca
Bigler C (2016) Trade-Offs between growth rate, tree size and lifespan of mountain pine (Pinus Montana) in the swiss national park. PLoS One 11:1-18. https://doi.org/10.1371/journal.pone.0150402

Bohnert HJ (1995) Adaptations to environmental stresses. Plant Cell Online 7:1099-1111. https://doi.org/10.1105/tpc.7.7.1099

Bohnert HJ, Jensen RG (1996) Strategies for engineering water-stress tolerance in plants. Trends Biotechnol 14:89-97. https://doi. org/10.1016/0167-7799(96)80929-2

Brickell C (1989) The royal horticultural society gardeners' encyclopedia of plants and flowers. Dorling Kindersley, London

Brunner I, Herzog C, Dawes MA et al (2015) How tree roots respond to drought. Front Plant Sci. https://doi.org/10.3389/fpls.2015.00547

Burg MB, Ferraris JD (2008) Intracellular organic osmolytes: function and regulation. J Biol Chem 283:7309-7313. https://doi. org/10.1074/jbc.R700042200

Catala R, Ouyang J, Abreu IA et al (2007) The arabidopsis E3 SUMO ligase SIZ1 regulates plant growth and drought responses. Plant Cell Online 19:2952-2966. https://doi.org/10.1105/tpc.106.04998 1

Clark J, Kjelgren R (1990) Water as a limiting factor in the development of urban trees. J Arboric 16:203-208

Clifford S (1998) The role of solute accumulation, osmotic adjustment and changes in cell wall elasticity in drought tolerance in Ziziphus mauritiana (Lamk.). J Exp Bot 49:967-977. https://doi. org/10.1093/jexbot/49.323.967

Cregg B, Dix ME (2001) Tree moisture stress and insect damage in urban areas in relation to heat island effects. J Arboric 27:8-17

De Micco V, Aronne G (2012) Morpho-anatomical traits for plant adaptation to drought. In: Plant responses to drought stress: from morphological to molecular features. Springer, Berlin pp 37-61

Dirr MA (1990) Manual of woody landscape plants. Stipes Publishing Company, Illinois

Faraloni C, Cutino I, Petruccelli R et al (2011) Chlorophyll fluorescence technique as a rapid tool for in vitro screening of olive cultivars (Olea europaea L.) tolerant to drought stress. Environ Exp Bot 73:49-56. https://doi.org/10.1016/j.envexpbot.2010.10.011

Farooq M, Hussain M, Wahid A, Siddique KHM (2012) Drought stress in plants: an overview. In: Plant responses to drought stress: from morphological to molecular features. Springer, Berlin, pp 1-33

Fini A, Ferrini F, Frangi P et al (2009) Withholding irrigation during the establishment phase affected growth and physiology of norway maple (Acer platanoides) and linden (Tilla spp.). Arboric Urban For 35:241-251

Hillier N (1993) Hillier manual of trees and shrubs. David \& Charles plc: Exeter

Holland V, Koller S, Brüggemann W (2014) Insight into the photosynthetic apparatus in evergreen and deciduous European oaks during autumn senescence using OJIP fluorescence transient analysis. Plant Biol 16:801-808. https://doi.org/10.1111/plb.12105

IPCC (2007) Climate change 2007: impacts, adaptation and vulnerability: Working Group II contribution to the fourth assessment report of the IPCC Intergovernmental Panel on Climate Change. Work Gr II Contrib to Intergov Panel. Clim Chang Fourth Assess Rep 1:976. https://doi.org/10.2134/jeq2008.0015br

Jane GT, Green TGA (1983) Utilisation of pressure-volume techniques and non-linear least squares analysis to investigate site induced stresses in evergreen trees. Oecologia 57:380-390

Jedmowski C, Ashoub A, Momtaz O, Brüggemann W (2015) Impact of drought, heat, and their combination on chlorophyll fluorescence and yield of wild barley (Hordeum spontaneum). J Bot. https:// doi.org/10.1155/2015/120868

Kalaji HM, Rac`ková L, Paganová V et al (2017) Can chlorophyll-a fluorescence parameters be used as bio-indicators to distinguish between drought and salinity stress in Tilia cordata Mill? Environ Exp Bot. https://doi.org/10.1016/j.envexpbot.2017.11.001 
Kirkham MB (2014) Principles of soil and plant water relations. Elsevier, Amsterdam 2 Edi

Kopinga J (1991) The effects of restricted volumes of soil on the growth and development of street trees. J Arboric 17:57-63. https://doi.org/10.1177/089484538601300207

Kozlowski ATT, Pallardy SG (2002) Acclimation and adaptive responses of woody plants to environmental stresses. Bot Rev 68:270-334

Lansac AR, Zaballos JP, Martin A (1994) Seasonal water potential changes and proline accumulation in mediterranean shrubland species. Vegetatio 113:141-154

Lenz TI, Wright IJ, Westoby M (2006) Interrelations among pressure-volume curve traits across species and water availability gradients. Physiol Plant 127:423-433. https://doi.org/10.111 1/j.1399-3054.2006.00680.x

Maréchaux I, Bartlett MK, Sack L et al (2015) Drought tolerance as predicted by leaf water potential at turgor loss point varies strongly across species within an Amazonian forest. Funct Ecol 29:1268-1277. https://doi.org/10.1111/1365-2435.12452

Martin PH (1999) Norway maple (Acer platanoides) invasion of a natural forest stand: understory consequence and regeneration pattern. Biol Invasions 1:215-222. https://doi. org/10.1023/A:1010084421858

McDowell NG (2011) Mechanisms linking drought, hydraulics, carbon metabolism, and vegetation mortality. Plant Physiol 155:1051-1059. https://doi.org/10.1104/pp.110.170704

Murakeözy ÉP, Nagy Z, Duhazé C et al (2003) Seasonal changes in the levels of compatible osmolytes in three halophytic species of inland saline vegetation in Hungary. J Plant Physiol 160:395401. https://doi.org/10.1078/0176-1617-00790

Niinemets $\ddot{U}$, Valladares F (2006) Tolerance to shade, drought, and waterlogging of temperate northern hemisphere trees and shrubs. Ecol Monogr 76:521-547. https://doi.org/10.1890/00129615(2006)076\%5B0521:TTSDAW\%5D2.0.CO;2

Ogaya R, Peñuelas J (2006) Contrasting foliar responses to drought in Quercus ilex and Phillyrea latifolia. Biol Plant 50:373-382. https://doi.org/10.1007/s10535-006-0052-y

Ougham HJ, Morris P, Thomas H (2005) The colors of autumn leaves as symptoms of cellular recycling and defenses against environmental stresses. Curr Top Dev Biol 66:135-160. https://doi. org/10.1016/S0070-2153(05)66004-8

Pallardy SG (2007) Transpiration and plant water balance. In: Physiology of woody plants, 3 Edit. Elsevier, Amsterdam pp 325-366

Parker WC, Pallardy SG (1988) Pressure-volume analysis of leaves of Robinia pseudoacacia L. with the sap expression and free transpiration methods. Can J For Res 18:1211-1213. https:// doi.org/10.1139/x88-186

Pattanagul W, Madore MA (1999) Water deficit effects on raffinose family oligosaccharide metabolism in coleus. Plant Physiol 121:987-993. https://doi.org/10.1104/pp.121.3.987

Percival GC, Sheriffs CN (2002) Identification of drought-tolerant woody perennials using chlorophyll fluorescence. J Arboric $28: 215-223$

Pflug EE, Buchmann N, Siegwolf RTW et al (2018) Resilient leaf physiological response of european beech (Fagus sylvatica L.) to summer drought and drought release. Front Plant Sci. https ://doi.org/10.3389/fpls.2018.00187

Postma JA, Jaramillo RE, Lynch JP (2008) Towards modeling the function of root traits for enhancing water acquisition by crops. In: Ahuja LR, Reddy VR, Saseendran SA, Yu Q (eds) Response of crops to limited water: understanding and modeling water stress effects on plant growth Processes, Advances in Agricultural Systems Modeling, ASA, CSSA, SSSA, Madison, WI. pp 251-275
Powell TL, Wheeler JK, de Oliveira AAR et al (2017) Differences in xylem and leaf hydraulic traits explain differences in drought tolerance among mature Amazon rainforest trees. Glob Chang Biol 23:4280-4293. https://doi.org/10.1111/gcb.13731

Rastogi NK, Raghavarao KSMS, Niranjan K, Knorr D (2002) Recent developments in osmotic dehydration: methods to enhance mass transfer. Trends Food Sci Technol 13:48-59. https://doi. org/10.1016/S0924-2244(02)00032-8

Regier N, Streb S, Zeeman SC, Frey B (2010) Seasonal changes in starch and sugar content of poplar (Populus deltoides $\times$ nigra $\mathrm{cv}$. Dorskamp) and the impact of stem girdling on carbohydrate allocation to roots. Tree Physiol 30:979-987. https://doi.org/10.1093/ treephys/tpq047

Roman LA, Battles JJ, McBride JR (2014) Determinants of establishment survival for residential trees in Sacramento County, CA. Landsc Urban Plan 129:22-31. https://doi.org/10.1016/j.landu rbplan.2014.05.004

Ryan MG (2011) Tree responses to drought. Tree Physiol 31:237-239. https://doi.org/10.1093/treephys/tpr022

Savi T, Bertuzzi S, Branca S et al (2015) Drought-induced xylem cavitation and hydraulic deterioration: risk factors for urban trees under climate change? New Phytol 205:1106-1116. https://doi. org/10.1111/nph.13112

Scherrer D, Bader MK-F, Körner C (2011) Drought-sensitivity ranking of deciduous tree species based on thermal imaging of forest canopies. Agric For Meteorol 151:1632-1640. https://doi. org/10.1016/j.agrformet.2011.06.019

Shamshiri R, Che Man H, Zakaria AJ et al (2017) Membership function model for defining optimality of vapor pressure deficit in closed-field cultivation of tomato. Acta Hortic 1152:281-290. https://doi.org/10.17660/ActaHortic.2017.1152.38

Sjöman H, Hirons AD, Bassuk NL (2015) Urban forest resilience through tree selection-variation in drought tolerance in Acer. Urban For Urban Green 14:858-865. https://doi.org/10.1016/j. ufug.2015.08.004

Sjöman H, Hirons AD, Bassuk NL (2018a) Improving confidence in tree species selection for challenging urban sites: a role for leaf turgor loss. Urban Ecosyst 21:1171-1188. https://doi.org/10.1007/ s11252-018-0791-5

Sjöman H, Hirons AD, Bassuk NL (2018b) Magnolias as urban treesa preliminary evaluation of drought tolerance in seven magnolia species. Arboric J. https://doi.org/10.1080/03071375.2017.14155 54

Smith AP (1986) Ecology of a leaf color polymorphism in a tropical forest species: habitat segregation and herbivory. Oecologia 69:283-287

Southwood TRE (1961) The number of species of insect associated with various trees. J Anim Ecol 30:1-8

Takahashi S, Murata N (2008) How do environmental stresses accelerate photoinhibition? Trends Plant Sci 13:178-182. https://doi. org/10.1016/j.tplants.2008.01.005

Tyree MT, Hammel HT (1972) The measurement of the turgor pressure and the water relations of plants by the pressure-bomb technique. $\mathrm{J}$ Exp Bot 23:267-282. https://doi.org/10.1093/jxb/23.1.267

Tyree MT, Cheung YNS, MacGregor ME, Talbot AJB (1978) The characteristics of seasonal and ontogenetic changes in the tissuewater relations of Acer, Populus, Tsuga, and Picea. Can J Bot 56:635-647. https://doi.org/10.1139/b78-071

van den Berk J, van den Berk P (2015) Van den Berk on trees, 2 Edi. Van den Berk Nurseries, Sint-Oedenrode

Vaz Monteiro M, Doick KJ, Lawrence V et al (2017) Investigation into the drought tolerance of broadleaf street trees using chlorophyll fluorescence. Acta Hortic. https://doi.org/10.17660/ActaHortic .2017 .1189 .83 
Verslues PE, Agarwal M, Katiyar-Agarwal S et al (2006) Methods and concepts in quantifying resistance to drought, salt and freezing, abiotic stresses that affect plant water status. Plant J 45:523-539. https://doi.org/10.1111/j.1365-313X.2005.02593.x

Volder A, Watson T, Viswanathan B (2009) Potential use of pervious concrete for maintaining existing mature trees during and after urban development. Urban For Urban Green 8:249-256. https:// doi.org/10.1016/j.ufug.2009.08.006

Webb SL, Kaunzinger CK (1993) Biological invasion of the DrewUniversity (New-Jersey) forest preserve by Norway maple (Acer platanoides L). Bull Torrey Bot Club 120(3):343-349

Weir I (2018) Spearman's correlation. In: Statstutor. http://www.stats tutor.ac.uk/resources/uploaded/spearmans.pdf. Accessed 5 Jan 2018
Woo NS, Badger MR, Pogson BJ (2008) A rapid, non-invasive procedure for quantitative assessment of drought survival using chlorophyll fluorescence. Plant Methods 4:1-14. https://doi. org/10.1186/1746-4811-4-27

Publisher's Note Springer Nature remains neutral with regard to jurisdictional claims in published maps and institutional affiliations. 